\title{
シップソーンパンナー・タイ族に括ける伝統的 \\ 農民統治の地形的分類 \\ 一「盈地国家」ッェンフン（固洪）王国の分析-
}

\author{
加藤久美子
}

はじめに

\section{1 問題の所在}

タイ族は，大陸東南アジア北部一带(1)においては山間盆地や谷閌の平地に居 住している。かつてここには盆地を基喽単位としたタイ族の「国策」か成立して いた。盆地ごとの政治統合は南西タイ諸語でムアン(2)と呼ばれ，被数のムアン が運合体を形成する例も各地で見られた。例えば，北部タイのラーンナータイ王

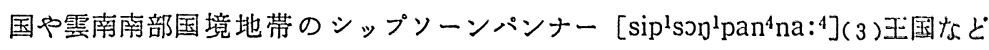
である(4)。

石井米雄は，この地域の伝統的な(5)タイ族国家は一般に「淮水力社会」的珄

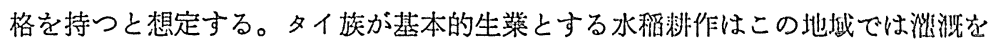

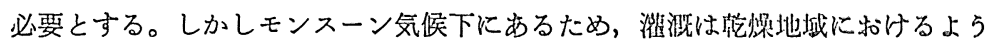
な決定的重要性を持ち得ない。用水の管制者も，社会に対して跑跀地域に特ける ほどの強力な支配権を行使することが国醀である。石斗はこのような祝点から，

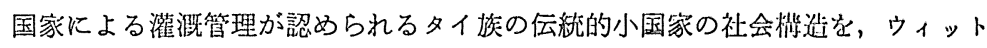

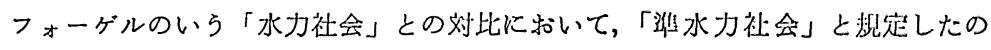
である [石井, $1975: 20-26]$ 。

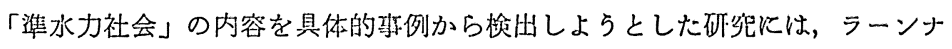
ータイに拈ける田辺繁治の研究 [1978] の他, シップソーンパンナーに拈ける加 治明 [1988」，馬場雄司 [1990b](6)の研究がある。

シップソーンパンナーの国家による灌溉管理の特㣲として, 加治は次の点を学 げる。政治権力は水利組織を統治機槛の中に組み入れ，それを通して水利打桨の

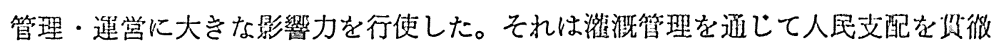
するというよりは，統治者層自身の直営田に十分な用水を供給してその䋊沙的罠 盤を固めるためであった。 


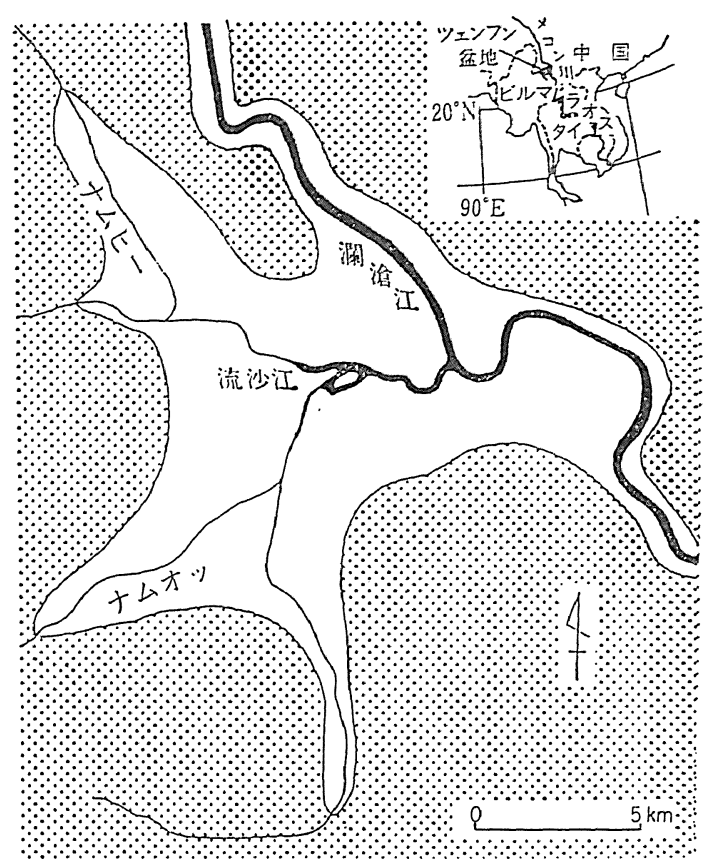

図1 ツェンフソ盆地 の河川

加治の言5シップソーンパンナーの政治権力とは, ツェンフン「tsenthun $\left.{ }^{1}\right]$ 盆 地（因 1）を直轄地としながらシップソーンパンナー全域をも統括する立場の権 力, つまり具体的にはツェンフン(7)の王でありシップソーンパンナーの王(8)で

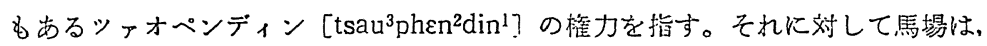
水利と関わる部分でのツァオペンディン権力の行使は, シップッーンパソナ一全 域に及ぶものではなく，值轄地であるッェンフン盆地に限られると反論する。

しかし, 加治も馬場も, 灌溉と密接な関係を持つはずの盆地内の具体的地形条 件については重視していない。また，水利整溉組織のみに䨩点を置き，行政組織

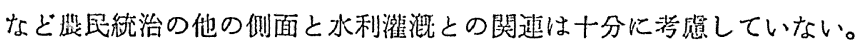

本稿の目的は、ッェンフン盆地を例に取り，灌溉に関わる地形的条件を考慮し た上でその伝統的秡民統治形態を検討することにある。そして，その分析結果を もとに先行研究を見值し，タイ族盈地国家の「準水力社会」的側面をどら捉える ベきが婨じてみたいのである。 
2 分析の視点——盆地内の地形条件

ムアンは，それぞれの王を持ち独自の惯習法的秩序を持った跳小の政治単位で あった。ムアンはまた，盆地といら閉鎖的空間に成立し，地理的・生熊学的にも 外部とは区別される政治環境単位を成していた[田辺，1978：181，212]。とれ ゆ古，この環境のタイ族政治組織について考察する時，まずムフンという単位を 検討する必要が市る。

ムアンの依抛する盈地内には灌溉が容易な所とそらでない所とが污る。由边 は，一般にラーンナータイの山間盆地は，主要河川沿岸の沖箖平野と㐿辺山地か ら流入する河川が形成した複数の小扇状地からなると指捅する。扇状地は比較的 急な傾斜を有するため，適切な取水殹と用水路を設ければ灌溉は容吻で吉った [田辺，1978：184]。そこには，いかゆる水力社会の理諭で指摘されるような，

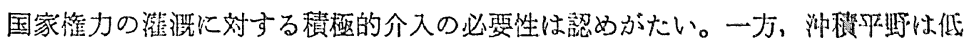

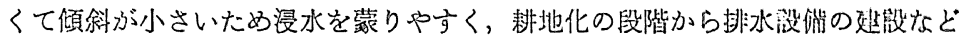
国家権力による比較的大規模な工策を要した可能性が大である。このような地形 的特徵は，ラーンナータイの盆地だけでなく山間盆地一般にかなり当掘的に見ら

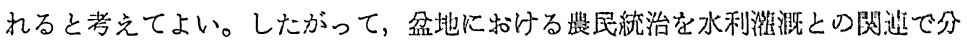
析する際には，このような盆地内の地形条件を洘愿する必要が物る。

\section{3 資 料}

先述の通り，本稿の分析対象はシップソーンパンナーのッェンフン分地で汸 る。シップソーンパソナーの大部分は，1950 年以後印菲人民背和国领となり，

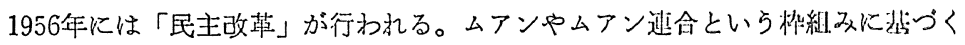
政治・社会制度は，基本的にはこの時まで存絽していた。

本高で主な情報源とするのは，1950 年代前半に行われた現地調植の跟少指(の)

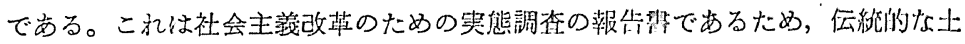

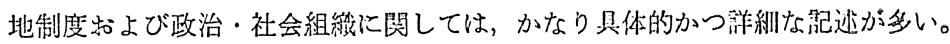
したがって本稿では, 土地制度, 政治・社会組総を地形的区分にあわせて分颣, 再検討してみたい。

$$
\text { I ッェンフンの水利㻴境 }
$$

1 ツェンフン盆地の地形

ッェンフン盆地は昆明の南西約 300 キロにあり, 面䖽は 75.05 平方キロメート 
東南フジフー瀝史と文化一 No. 20, 1991

ル，平均海技高度は550メートルである [譚，1989：117]（図1）。盆地を貫流す

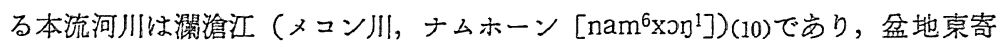
りを北西から南東へ流れている。そこへ西方山地から流下する流沙江（ナムハー [nam $\left.\left.{ }^{6} h a:^{3}\right]\right)$ が合流する。盆地は，この合流点より西側に広く開けている。この 盆地に周辺山地から流れ込む諸河川のうち，最大のるのがナムオッ $\left[\mathrm{nam}^{6} \mathrm{Jt}^{2}\right]$, それに次ぐのがナムヒー [nam6hi:3] であり，それぞれ南側と北側から流沙江に 合流する。河川の流れ方からも分かるように，盆地は大まかに見て東へ傾斜して いる。

灌溉との関連で見ると，盆地内部は地形的に次のように二分できる。その1つ は,ナムオッ，ナムヒーなどの河川が作る扇状地の連なる盆地西部である（以 下, 扇状地部と呼ぶ)。も51つは扇端直下から潤滄江河岸までの地域であり, その大部分は沖積平野からなる(以下, 沖積平野部之呼ぶ)(11)。

2 ツェンフン盆地に沶ける伝統的水利環摬(12)

（1） ツェンフン盆地の水路

ツェンフン盆地に打ける灌溉は, 河川の水を堰と用水路によって導水・分水し ていくという方法を取っていた(13)。この盆地の灌溉用水路の中で特に大きいる のとしては，資料中に 5こが挙げられている [歴三 : 78-79］[総二：67-70］。袁 1は，それらにも51本を加光(14)（以下，記号を用いて水路 $\mathrm{A}-\mathrm{F}$ と示す），そ の様々な状沉を比較したものである。また, 図 2 は, それら 6 水路の流路(15) と 受益村落の分析を図示したものである。

これら 6 水路は，それぞれの用水を供給する河川といかなる関係にあるかによ り 2 形態に分類できる。すなおち，水路 $\mathrm{A} \cdot \mathrm{B} \cdot \mathrm{D} \cdot \mathrm{E}$ は，河川のつくる扇状地 扇媔部で河川から幹線用水路に水を引き，そこから順次分流させていくという形

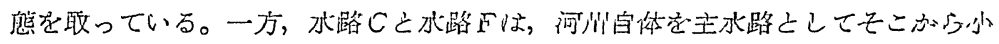
水路穵分流させるといら形热の水路であった（垶 1，図2）。

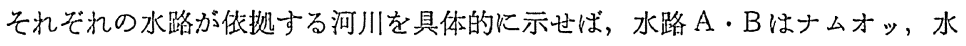

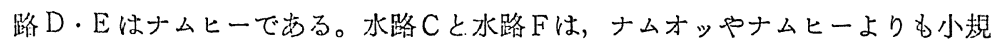
模の河川を用いている。このような水路状沉は, ッェンフン盆地では本流河川の 阔泠江やそれに次ぐ摆模の流沙江が灌溉に利用されなかったことを説明してい る。熦涀に利用されたのはナムオッをはじめとする周辺山地から流入する河川で あった。その中で, ナムオッとナムヒーといら比皎的規模の大きい 2 河川の流水 


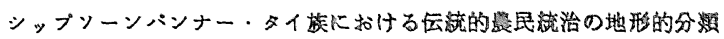

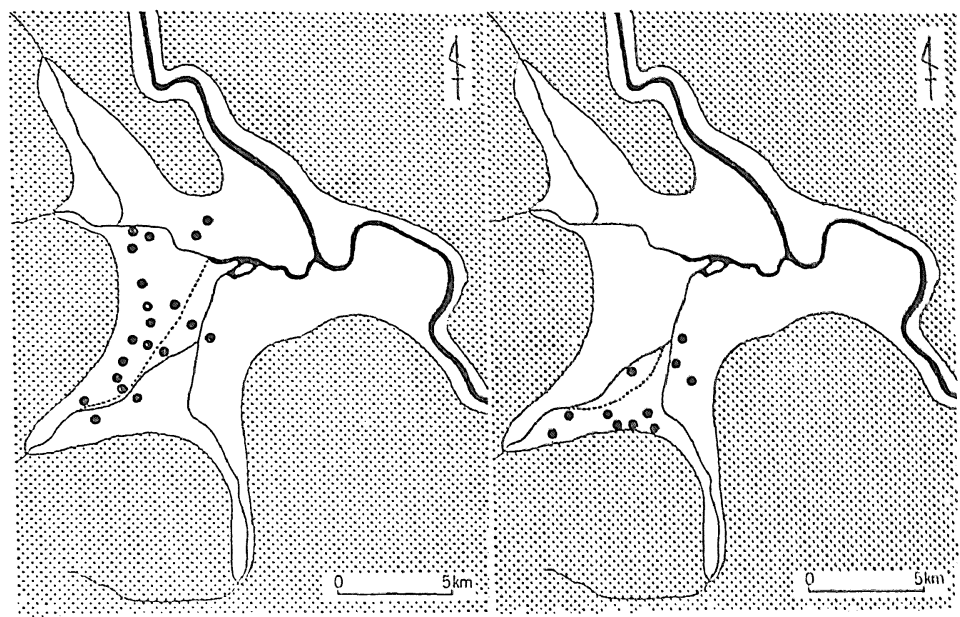

图 2-1 水路 4 受益村落の分布

图 2-2 水路B受益村落の分打

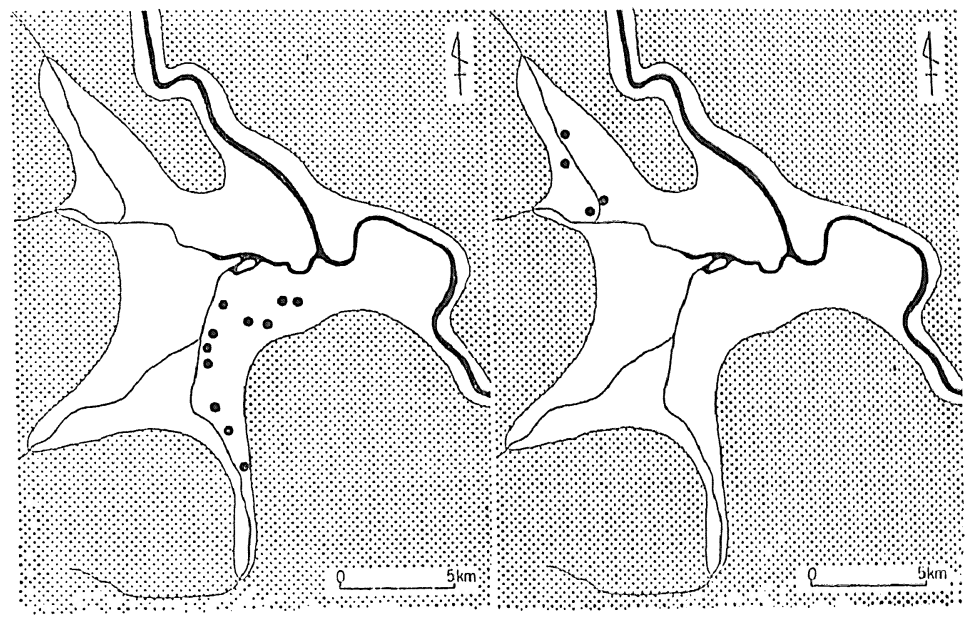

因 2-3 水路 C受益村落の分布

因2-4 水路D受益村洛の分猚 
東南フジフー歷史と文化一 No. 20, 1991

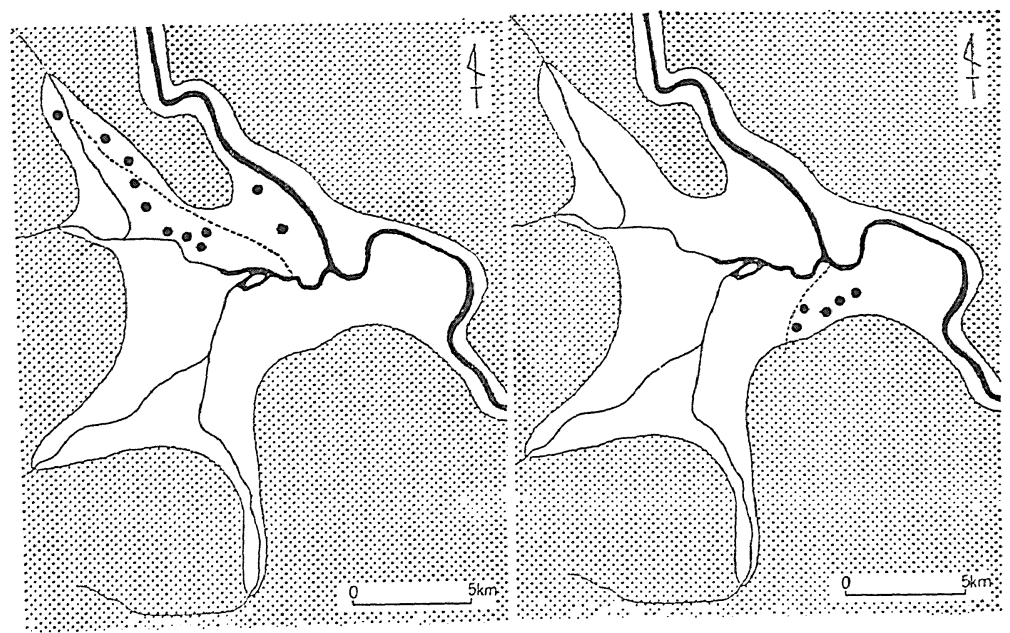

因 2-5 水路 $\mathrm{E}$ 受益村落の分布 因 2-6 水路 $\mathrm{F}$ 受益村落の分布

表 $1 \%$ ッフンの大用水路 (出典 [総二 : 67-70])

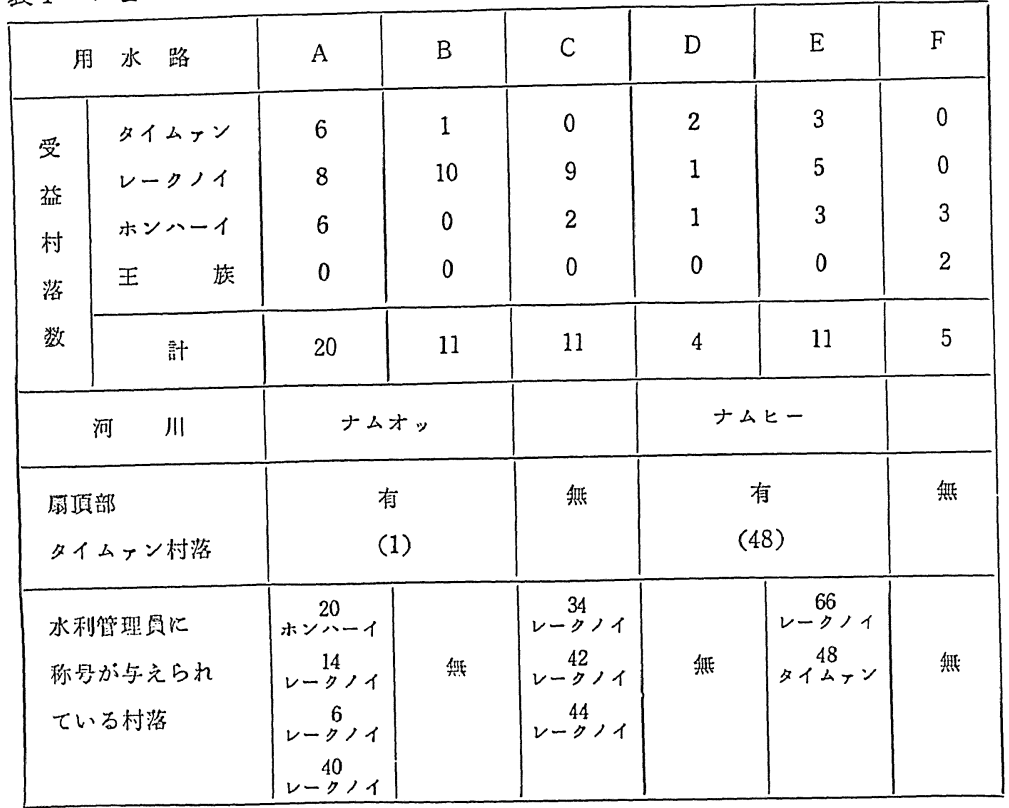
水路名 $\mathrm{A}:$ ムテンナーヨン
$\mathrm{B}$ ：ムァンナムシン
C : ムェンパーンファーッ
D：ムェンナムトン
$E$ : ム ンツェーラーイ
F：ムァンホイハー 


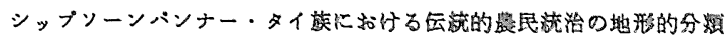

は扇頂部で幹線用水路へと取水される形態を取り，それら2 河川よりす小䙺模の 他の河川はそれ自体が用水路として使われていた。ツェンフン盆地の水路は，取 水する河川の規模によって，以上の 2 形態に分かれるのである。

（2）扇状地部における水路

受益村落の分布（図 2）から明らかなように，上記 6 水路の5ち扇状地部の洲

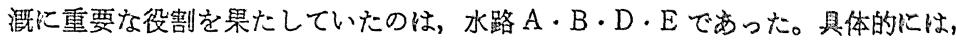

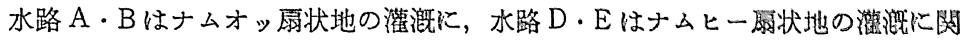
わっていた。

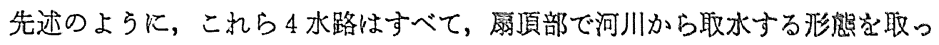
ていたため，取水口を掌握でさる羽頂部がそれらの水管理の扰点となっていた。 また，扇状地は傾斜があって灌溉が容易なため，これら水路の羽頂から端に至 る部分は比較的早い時期に開設されていた可能珄:が高い(16)。

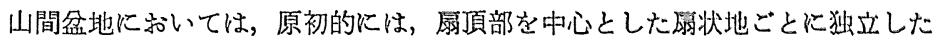
灌溉の系ができていたと考えられる [田辺，1976：682，1978：191] [㬏谷，19 $78: 167]$ 。したがってこの盆地でも，原初的にはナムオッ扇状地の症，ナムヒー 扇状地の系が形成されていたと考えるのが自然であるう。

（3）沖箖平野部に执ける水路

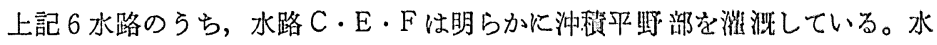
路 $\mathrm{A} \cdot \mathrm{B}$ も下流域で沖積平野の灌溉に関わると予想される。すなわち水路D除 く 5 水路が沖蕒平野部灌溉に関わっていた可能性がある（図 2）。

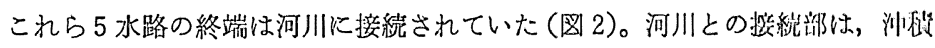

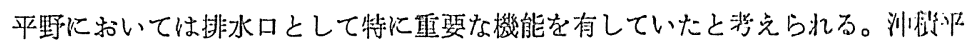

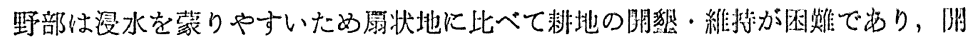
懇に先たってまず排水のための水路を建設しなければならなかった。その缧，非 水口が特に重要であるのは言うまでもない。

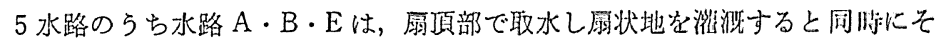
れに続く沖䅡平野をる灌溉する。扇状地の水路が早期に開設されていたい化性に

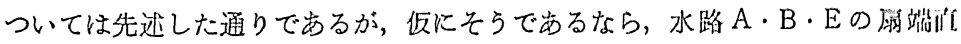
下から排水口まですなわち沖積平野を流れる部分は，沖积坐野の排地のために㷋 から延長されたということになろう。

（4）水利組緎

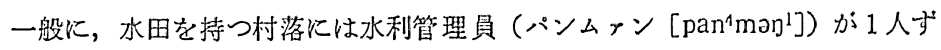


東南アジー歷史と文化一 No. 20, 1991

つ存在する。禎数の村落が用いる水路については, 最上流, 最下流の村落の水利

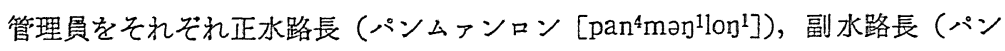

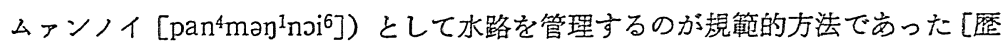
三:78] [総二 : 67]。

水路によっては，定められた村落の水利管理員が統治権力より称号を与えら れ，水路全体の管理を行っていた（以下，水利官と仮称する)(17)。水利官はあく まで統治権力の定めたものであり，必ずしも規範的意味での正・副水路長とは一 致しない。それは，1水路に 3 人以上の水利官が存在し(18)，しかも最上流，最 下流以外の村落に直かれているなどの事例（流1など）から明らかである。

水利官は，適切な水の分配量を計算してその通り分配されているかを調べた り，水利施設修理のまとめ役となったりした［歷三: 78-79］[総二:67-70］。水 利施設修理への不参加や盗水の処罚貮任も水利官に委祆られていた。

6 大水路のらち, 水利官が置かれているのは, 水路 $\mathrm{A} \cdot \mathrm{C} \cdot \mathrm{E}$ においてのみで ある。これらの水路のみに水利官が設置された理由については， $N-2$ で詳述す る。

$$
\text { II ツェンフンに和ける農民集団の伝統的類別 }
$$$$
\text { 一タイムァンとクンファンツァオ }
$$

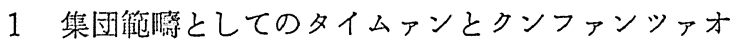

ツェンフンといらムアンの統治形態を分析する際, その前提として考虑されれ ばならないのは，ムアンの住民が大きく分けて4つの集団範眼に手別されていた

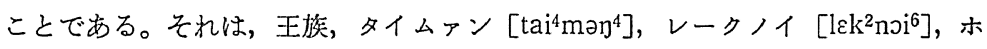

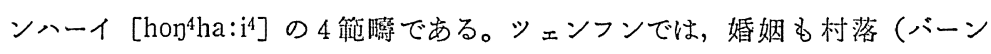

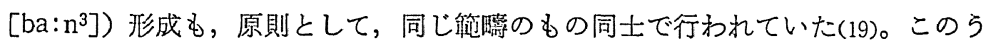

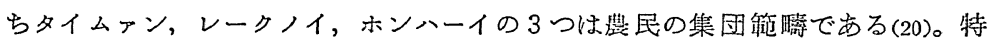
にレークノイとホンハーイは, クンファンツァオ [kun $\left.\mathrm{han}^{4} \mathrm{tsau}^{3}\right]$ という呼称の もとに一括して报われる。

王族，タイムァン，レークノイ，ホンハーイの区分は行政組織上にも反映され ていた。因３は，1950年熲まで使われた行政系統を示したものである。行政単位 は，小さいものから順に村落，ホーシップ [ho: $\left.{ }^{1} \operatorname{sip}^{1}\right]$, ロン $\left[\mathrm{log}^{4}\right]$ となってお り，最上位行政単位であるロンは 4 つ存在していた(21)。また，ホーシップの中 でもホーシップクンクー（発音の詳細は不明）とホーシップホンハーイ［ho: ${ }^{1} \mathrm{si}$. 


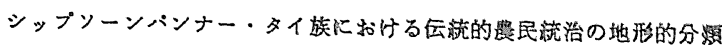
ホーシップクンクー $\star 64 \mathrm{E} \star 65 \mathrm{e} \star 70 \mathrm{~F} \star 71 \mathrm{CF} \star 72 \mathrm{~F} \star 73 \mathrm{~F} \diamond 74 \mathrm{~F} \star 77 \mathrm{f} \star 78 \mathrm{f}$

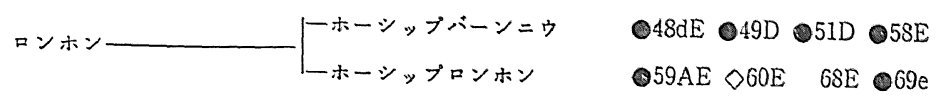

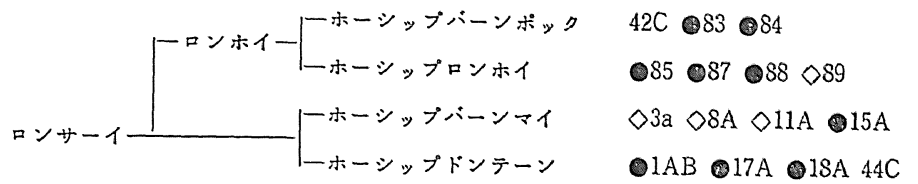
—ホーシップホイソー４a 5a 50D ऽ52D 54E 56E 57E

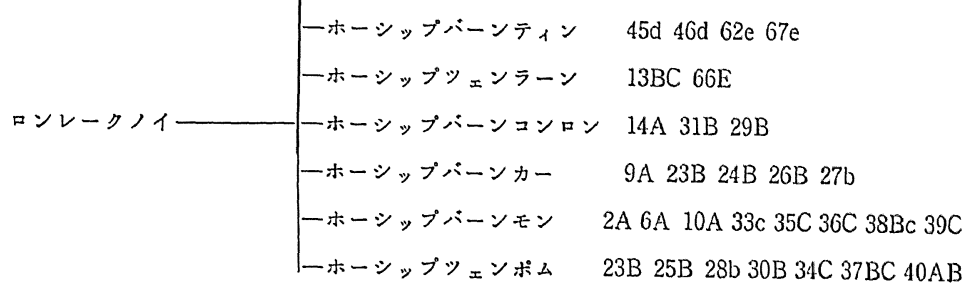
43C 90

ホーシップホンハーイ $\diamond 12 \mathrm{~A} \diamond 13 \mathrm{~A} \diamond 19 \mathrm{a} \diamond 20 \mathrm{~A} \quad 21 \mathrm{~A} \diamond 22 \mathrm{aC} \diamond 32 \mathrm{c} \diamond 55 \mathrm{E} \diamond 60 \mathrm{E}$ $\diamond 61 \mathrm{E}$

凡例 数字…村落番号

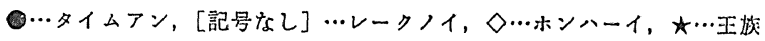
$\mathrm{A} \sim \mathrm{F} \cdots$ 水路 $\mathrm{A} \sim$ 水路 $\mathrm{F}$ それぞれを利用。 $\mathrm{a} \sim \mathrm{f} \cdots$ 水路 $\mathrm{A} \sim$ 水路 $\mathrm{F}$ それぞれの付近に立地（利用はしない）。

図 $3 \%$ ッフンの行政組織(出典 [問四: 73])

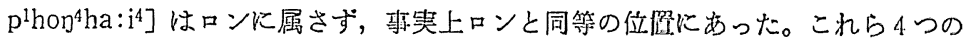

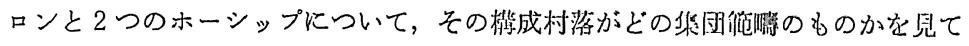

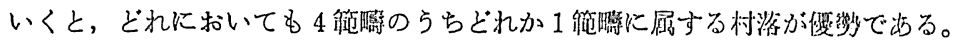

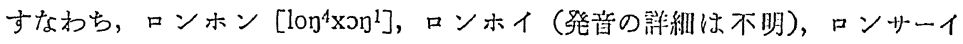
$\left[\mathrm{lon}^{4} \mathrm{sa}: \mathrm{i}^{4}\right]$ はタイムтン儤熒であり，ホーシップクンクー，ロンレークノイ $\left[\mathrm{log}^{4} \mathrm{Ek}^{2} \mathrm{n} \mathrm{i}^{6}\right]$ ，ホーシップホンハーイはそれ艺れ王族，レークノイ，ホンハーイ

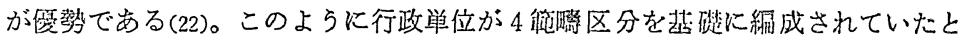
いう事壱から，農民統治全般がその区分を前提になされていたことが予测される。

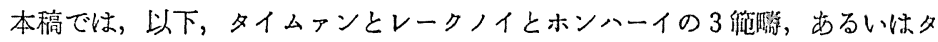

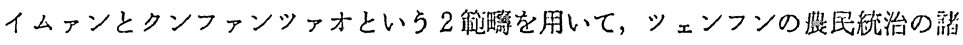
侧面を分析していく。 
束南フジアー歴史と文化一 No. 20, 1991

表 2 村落起源伝承（村落形战者あるいは伝承中への現れ方）

a：ムアン最古の村落,ムアン創建伝䒺に現れる村落

a 1 ムフン垓古のタイ族 7 村 [世系: $17,74,167,224]$

a 2 ムフン最古のタイ族14村 [歷四: 198]

a 3 ムフン最古のタイ族14村〔総二:89」

a 4 パャーフーラウォー（ムフン創建主）到来後の践争で残った10村 [歷四：211]

a 5 パャーフーラウォ一到来後つくられたムフン最古のタイ族15村 [歷三：16]

a 6 バャーフーラウォーの随員 [歷四: 198]

a 7 バャーフーラウォーの随員 [歴四 : 78]

a 8 パヤーフーラウォーの随員 [世系 : 136]

a 9 バャーフーラウォーの侧近が管輅した村落 [歴三：16]

a 10 王族の㷋蓇をさがしに行く12人の使者のリーダーを出した村落 [世系：66他］

b : 統治者の悡的従属民出自の村落

b 1 王の家内淘仕人 [歷四：236]

b 2 「寺奴」(カーワット) [総二 : 7]

b 3 村落37付きのパャーの家内带仕人

b 4 王の家内泾仕人 [ 櫪四: 78,93]

b 5 パャーチュンハーンとともにやって来た人ね

b 6 ツェオッェンハーの家内奉仕人

b 7 王のための料理人*（別のムアンから贈りものとして，あるいは戦争の賠萴としてや ってきたもの)

b 8 王の家内替仕人 [総二: 66]

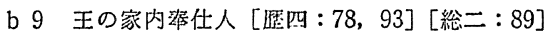

b 10 還俗した「小和尚」(パノイ)(ムアン外から王がめとった妻.あるいはムアン外から 米た高侻についてきたもの）[歷四：78]［総二：89]［世系：137]

b 11「寺奴」(ムアン外から高僧についてきたもの) [歴四：79]

b12 王のために明かりをともす仕本をしにムアン外から来た人及 [歷四：79]

b 13 王の家内浲仕人 [ 歷四 : 79, 192]

b 14 王の呼びよせた人々 [歷四 : 78]

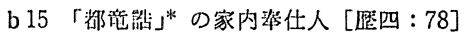

b 16 「召意納呮」*の呼びよせた人々［歴四：78］

b 17 「召頂峨」*の呼びよせた人々 [ 歴四：78，141]

b 18 王の家内泥人

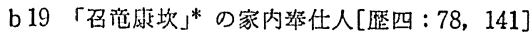

b 20 「召论納干」*の家内华仕人 [麼四 : 78]

b21水路を揤らせるために，「都竟誥」゙が連れてきた人々 [歷四：78，82］

b 22 シヶオロンバーサーッの家内奉仕人 [歴四：168]

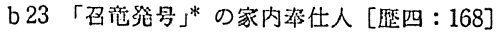




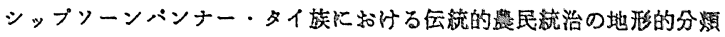

b 24 別のムアンからの綫争捕齿

b 25 ワットロン（「都市」内にあるムアンの中心寺院）の「寺奴」

b 26 \%ャオカーッ*がカーッローン(「都市」内にあるムフンの中心的市揚) の守衛のた めに呼びよせた人々 [歷四：168]

c：移民が形成した村落

c 1 ムテンラーパーントンから来た人タ

c 2 元江から来た人々

c 3 耿馬から来た人な

C 4 チンウィーから来た人タ

c 5 徳宏から来た人\&

c 6 晾谷から来た人\&

c 7 飢篊のため避難してきた人々が合流 [総二 : 66]

c 8 ムェンハーイなどから来たタイ・ルー族（普文一带から来た淡漛㨴の集落を含む。）

c 9 \%ェントゥンから来た漢傣族

C 10 景谷から避難してきた人々（当時から見て40 50年あまり前）[圂四：78]

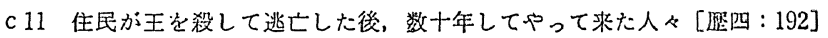

c 12 別のムアンから「負担」を逃九てやってきた人々［暨四：193]

c 13 元江, 墨江付近から来た人々（当時から見て50年汪ど防）

$\mathrm{d}$ ：分村，移㓰村 (ムアン内。数字は村落番昂。)

d 11 からの分村 [嚦四: 80,119]

d 244 にある白塔付近からの䔟䡃 [歷四: 211]

d 33 からの分村

d 4 14からの分村

d 5 1からの分村 [歴四: 207]

d 631 からの分村

d 737 から分村

d 850 からの分村

d 9 1からの分村 [厢四：193]

e：その他

e 1 先住哭星族の拠点 [世系: 64他]

e 2 八二落起源

e 3 タイムテンからホンハーイへの転歇

e 4 䓡傣埃起源 
東南フジフー歷史と文化一 No. 20, 1991

\begin{tabular}{|c|c|c|c|c|c|c|}
\hline & 村落番号 & \multicolumn{5}{|c|}{ 村落起源伝承の種類 } \\
\hline $\begin{array}{l}\triangle \\
\text { Ј } \\
\text { У }\end{array}$ & $\begin{array}{r}1 \\
15 \\
17 \\
18 \\
21 \\
48 \\
49 \\
51 \\
58 \\
69 \\
83 \\
84 \\
87 \\
88\end{array}$ & 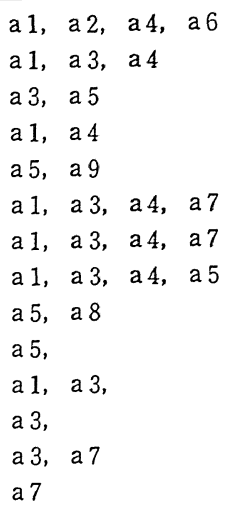 & b 1 & c 1 & d 1 & \\
\hline $\begin{array}{l}2 \\
1 \\
y \\
1 \\
1 \\
3 \\
y \\
2 \\
7 \\
7 \\
2 \\
\% \\
7 \\
0 \\
0\end{array}$ & $\begin{array}{r}4 \\
5 \\
6 \\
9 \\
16 \\
23 \\
25 \\
28 \\
29 \\
30 \\
31 \\
33 \\
35 \\
37 \\
39 \\
40 \\
44 \\
45 \\
46 \\
47 \\
50 \\
54 \\
56 \\
57 \\
62 \\
66 \\
67 \\
68\end{array}$ & $\begin{array}{l}\text { a } 3 \\
\text { a } 5 \\
\text { a } 9 \\
\text { a } 1 \text { a } 3, \text { a } 4, \quad \text { a } 10\end{array}$ & $\begin{array}{l}\text { b } 3 \\
\text { b } 4 \\
\text { b } 5 \\
\text { b } 6 \\
\text { b } 7 \\
\text { b } 8 \\
\text { b } 4 \text {, b } 9 \\
\text { b } 10\end{array}$ & $\begin{array}{l}\text { c2, c3 } \\
\text { c } 4 \\
\text { c } 3 \\
\text { c } 3\end{array}$ & d 8 & $\begin{array}{l}\text { e } 1 \\
\text { e } 1\end{array}$ \\
\hline
\end{tabular}




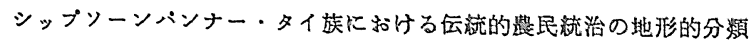

\begin{tabular}{|c|c|c|c|c|c|c|}
\hline 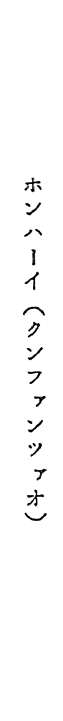 & $\begin{array}{r}3 \\
8 \\
11 \\
12 \\
13 \\
19 \\
20 \\
22 \\
32 \\
41 \\
52 \\
55 \\
60 \\
61 \\
70 \\
71 \\
74 \\
75 \\
77 \\
89\end{array}$ & a 3 & $\begin{array}{l}\text { b } 11 \\
\text { b } 12 \\
\text { b } 11 \\
\text { b } 13 \\
\text { b } 14 \\
\text { b } 15 \\
\text { b } 16 \\
\text { b } 17 \\
\text { b } 18, \quad \text { b } 19 \\
\text { b } 20 \\
\text { b } 20 \\
\text { b } 21 \\
\text { b } 22 \\
\text { b } 23, \quad \text { b } 24 \\
\text { b } 25 \\
\text { b } 26\end{array}$ & $\begin{array}{l}\text { c } 9, \quad \text { c } 10 \\
\text { c } 3 \\
\text { c } 11 \\
\text { c } 12 \\
\text { c } 10 \\
\text { c } 10\end{array}$ & $\mathrm{~d} 9$ & e 4 \\
\hline
\end{tabular}

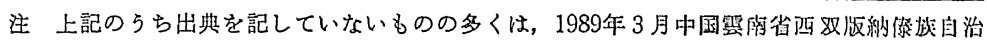
州において，筆者自身の中国語での聞き取りにより得られた嘴報である。インフォーマン

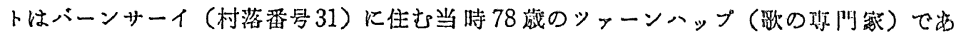

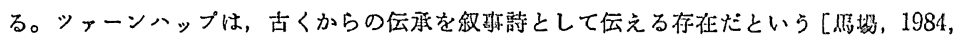
1990a]。また，表中，接付したのは官僚名である。そのらち淡字で鼠かれているのは， 中国語音訳表記である。

\section{2 伝承の中でのタイムァンとクンファンツァオ}

ツェンフンに伝わる様々な伝承中には，個々の村落がいかなる者によって形成 されたか，また，形成時に統治権力といかなる関係を持っていたかについて蚛れ ているものが多数ある(表 2)。

タイムァン村落の大半は何らかのムアン㓣建伝承（表中， $\mathrm{a}$ 纇の伝承）との四 わりを持っている。ムアン創建伝承の中には統治権力の到来前から居住していた 先住民に言及しているものがあり（表中の $\mathrm{a} 1-3 ， \mathrm{a} 10$ ），その中に少住民㫦洛と して名前があげられているタイムァン村落も多い。このようにタイムテンとい

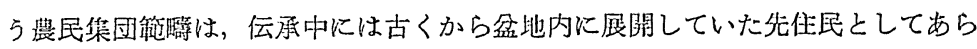
われてくるのである。

一方, ホンハーイ村落の大半は, 統治者の私的従属民（b頪の伝承）あるいは 


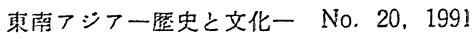

ムフン外からの移民（c 類の伝承）によってつくられたといら伝承を持つ。レー クノイ村落は，ムアン創建伝承に現れるるのも一部あるが，やはり統治者の私的 從属民や移民起源の伝承を持つものが多い。またレークノイ村落の多くは，言 に示したもののほか，洪水の被害を逃れてムァンラーオ [mən $\left.{ }^{4} \mathrm{la}: \mathrm{u}^{4}\right]$ から移住 したという伝承を持つ[歷四：78］[雲南調査組，1958：258]。統治者の私的従 属民が統治者の命を受けて村落を形成したことは言うまですないが，移民が村落 形成をする時も統治権力の許可が必要とされた。このどちらの場合も，村落は統 治者たちの指定する埸所につくられた。つまり，一般にクンファンツァオという 患民集団筑略は定住時から統治権力との密接な関わりを持つと捉えられていたの である。

以上のように，伝承には，タイムァンは先住者として，クンファンツァオは統 治権力成立後に移住した統治者の従属民として描かれている。タイムァン，クン ファンツァオといら言葉の直訳的な意味は，それぞれ「ムアンの自由民」，「主人 の家内非仕人」であり [田辺，1984:141]，それは伝承中の位置つけとも対応す ることになる。確かに，タイムァン村落で比較的新しい時期に分村として成立し ためのやクンファンツァオ村落で比較的古い時期から定住していたものの存在の

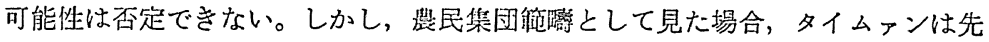

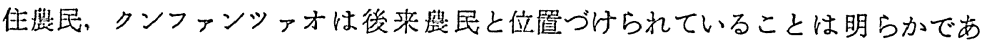
る(23)。

3 徭役体系の中のタイムァンとクンファンツァオ

ッェンフンで「徭役」として位置づけられているものは，2つに大别される。

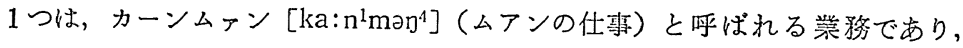
水路·道路・橋の築造や修築, 守謢霊祭祀, ムアン外との戦争への従電, 中国へ の負納負担などがその内容である [歷四：139-141]。もう1つ注統治者層への直

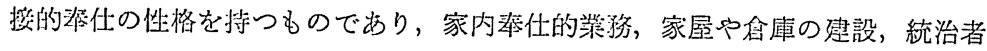
䣫学田からの上納米の榆送などがあげられている [歴四：141-145]。

このらち、タイムァンが中心的に携わるのはカーンムァンであった。カーンム

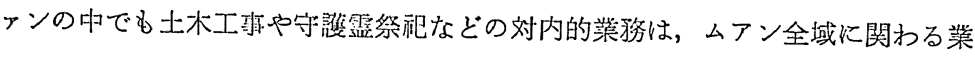
務ではなく，より小さな地域内で完結するものであった(24)。また，それらは公 洪菜務的性格を持つものであり，小地域内で完結するがゆえに，統治権力からの 強制によらずに行われた承例も多い。つまりカーンムァンの多くは，農民が小地 


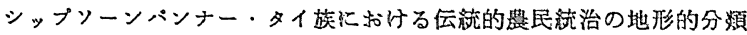

域単位で自律的に行う公共業務に，統治権力が形式的に関わり(25)「皃役」とい

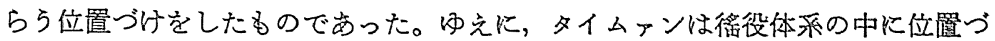
けれてはいても，事実上は自立的立場にあったのである。

一方，クンファンツァオは，流治者層への直接的轩仕の性格を持つ多種多様な 徭役に中心的に携わっていた [憷四：139-145]。これは，クンファンツテオの統 治権力への従属度がきわめて強いことを意味している。ッェンフンの雪筫上の䱦

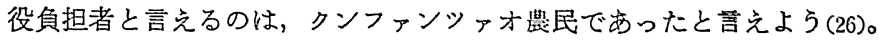

\section{4 土地制度の中でのタイムァンとクンファンッァオ}

村落は固有の領域を持ち，領域内の耕地は当該村落によって管理される。耕地 は世帯を単位として村民にほぼ平等に割り振られ，村民労㰾力に対して過不足が ある場合は村落間で貸借が行われた。

ツェンフンの耕地は, 村田（ナーバーン [na: $\left.{ }^{4} \mathrm{ba}: \mathrm{n}^{3}\right]$ ), 官僚田（ナーポーラ 一ム [na: $\left.\left.{ }^{4} \mathrm{po}:{ }^{1} \mathrm{la}: \mathrm{m}^{1}\right]\right)$ ，王田（ナーツァオペンディン [na: $\left.{ }^{4} \mathrm{tsau}^{3} \mathrm{phen}^{2} \mathrm{din}^{1}\right]$

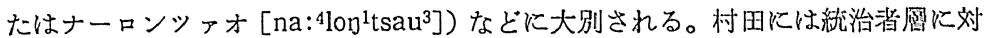

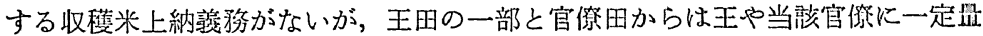
の収穫米(27)が納入されねばならない。その他の王时は，徭役によって非作され， 表 3 一村落あたりの耕地面積と㳫䒠上の米の取り分（飞均）

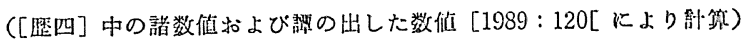
能位：ナーニ的 1.7 フール

\begin{tabular}{|c|c|c|c|c|}
\hline & タイムェン & $\begin{array}{l}\text { タイ公厂ン } \\
\text { (铔地部) }\end{array}$ & レークノイ & ホンハーイ \\
\hline$\frac{\text { 柋報のある村落数 }}{\text { 総数 }}$ & $\begin{array}{c}9 / 16 \\
(56 \%)\end{array}$ & $\begin{array}{l}7 / 11 \\
(64 \%)\end{array}$ & $\begin{array}{r}23 / 42 \\
(55 \%)\end{array}$ & $\begin{array}{c}8 / 20 \\
(40 \%)\end{array}$ \\
\hline 村 田 & 1937 & 2430 & 463 & 4 \\
\hline 官 综 田 & 600 & 579 & 1268 & 436 \\
\hline 王田（全約地以外） & 133 & 171 & 260 & 0 \\
\hline 計 & 3173 & 3672 & 2131 & 491 \\
\hline 甛実上の米の取り分 & $195 \mathrm{t}$ & $232 \mathrm{t}$ & $46 \mathrm{t}$ & $29 \mathrm{t}$ \\
\hline
\end{tabular}


東南アジフー歷串と文化一 No. 20，1991

全收穛が王に納められる（表3では，全納地という言葉で示す）。1つの村落領 域内には，これらのうち何種かが並存する場合が多かった[摩四：95-99，121131]。

一般に，クンファンツァオの村落には官僚田が優勢であるのに対し，タイムっ ソの村落では村田が優勢であった（表3）。また，官僚田，王田の所在地につい ては，タイムァン村落にあるるのよりクンファンツァオ村落にあるものの方が， 量的には遥かに多いようである(28)。

耕地の面䅡については, タイムテン，レークノイ，ホンハーイの順に村落所属 耕地が少なくなる傾向にある(29)。村落の事実上の米の取り分を各類型の平均に ついて算出し比㮁しても，タイムァンはレークノイの 4 倍以上，ホンハーイの 6 倍以上を猚得しており，王倒的にタイムァンが富裕な状態にあったことが分かる (表 3)。

このように各種耕地の分布状況は，タイムァンの統治権力からの相対的独立 性，自倠性を明示している。また，米の生産という面で統治権力を経済的に支党 るのは，暃にクンファンツァオ㓙民であったことも明らかにされた。

\section{5 小 結}

以上の, 沺役や耕地状沉の考察から，クンファンツァオは統治権力への従属度

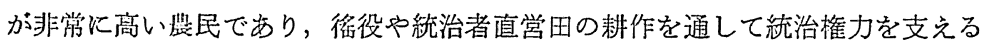
存在であることが磼認された。それに対してタイムァンは，独立的，自律的な農 民であった。このよらなクンファンツァオ, タイムァン間の差哄は，伝承に見ら れるクンファンツァオの後来從属民としての姿, タイムァンの先住民としての姿 と刘応するものである。以上をふまえ，次に，タイムァン，クンファンツァオそ れぞれの村落立地を灌䀝環境の上から清えてみたい。

\section{IIIIタイムァンと水利灌激}

1 タイムァンの村落立地

タイムェン村洛は，测滄江左岸の一村（笔者が付した村落番号では69）を除 けば，東荓部の周辺支谷の村準群と盆地内部の扇状地部村落群に二分される（因 4)(30)。支谷にしても扇状地にしても, 堰灌溉を行うのが此較的容易な地形的条 件にある。タイムァンは，いわば，個別の在地水利組織による水利施設の建設之 維持が可能な地域に居住していたことになる(31)。 


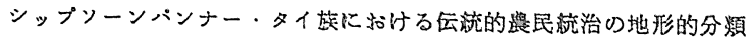

図 4 タイムァン村落の分 布

(2) ロンホン

(0) ロンホイ

○ ロンサーイ

記号なし ホーシップホン八 $-1$

数字 村落番号

$\mathrm{A} \sim \mathrm{E}$ 水路 $\mathrm{A} \sim$ 水路 $\mathrm{E}$ それ ぞれを利用

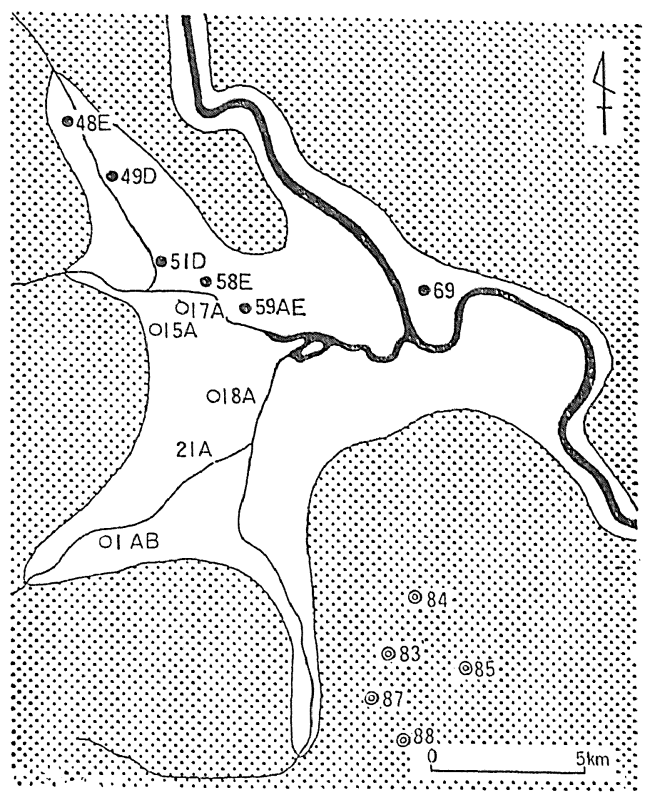

図 5 水利管理員に称号が 与えられている村落の分 布

ㄱำタムェン

記号なしレークノイ

$\diamond$ ホンハー1

数字 村落琶昂

$\mathrm{A} \sim \mathrm{E}$ 水路 $\mathrm{A} \sim$ 水路 $\mathrm{E}$ それ ぞれの水利官

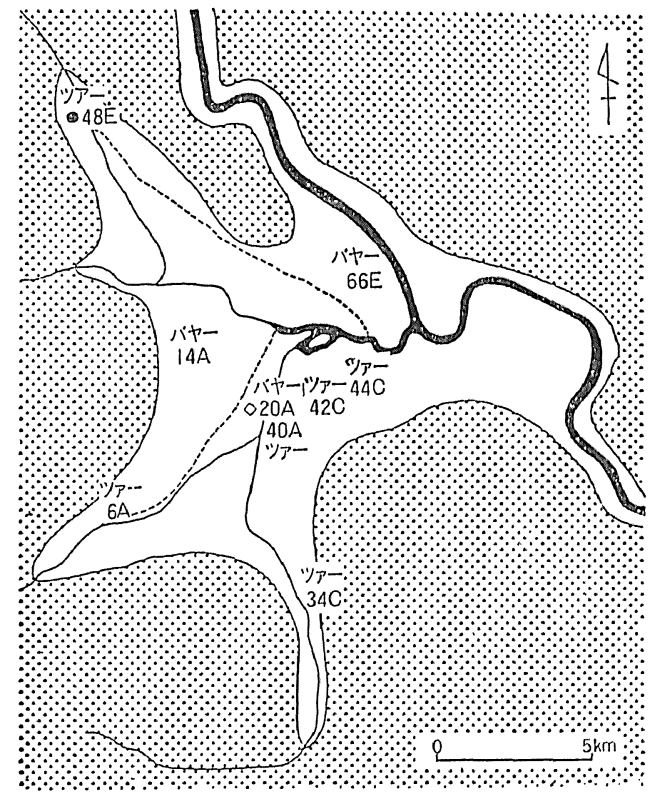


東南フジフー歷史と文化一 No. 20，1991

扇状地部は，扇頂部で取水する堤灌溉を行っている限り，扇状地ごとに独立し た灌浿の系に分けられる。したがって灌溉との関連で言えば，タイムァンの扇状 地部村落群は更にナムオッ榇状地村落群とナムヒ一扇状地村落群に二分できる。 もし伝承の通りタイムァンが先住辳民であるとすれば，原初的にはナムオッ扇状 地，ナムヒ一庼状地それぞれにおいて，タイムァンのみで灌溉の系を形成してい た可能性は大きい(32)。

また，扇状地灌溉においては扇頂部を押さえたすのがその扇状地全体の灌溉を 掌握する立埸にたつが，扇状地部タイムァン村落の分布を見ると，ナムオッ扇状 地，ナムヒ一扇状地の扇頁部にはそれぞれ 1つずつタイムァン村落が存在してい る。ナムオッ扇状地のもの（村落番号 1) はバーンターハーンムァン [ba: $n^{3} \mathrm{ta}$ :

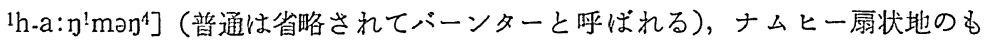
の（48）はバーンターホームァン [ba: $\left.\mathrm{n}^{3} \mathrm{ta}:{ }^{1} \mathrm{ho}:{ }^{1} \mathrm{mon}^{4}\right]$ (同じく省略されてバー ソホームァンと呼ばれる）といら名称を持つ。それぞれ「ムアンの尾の港の村」， 「ムアンの頭の港の村」という恝味であり，一対をなしているのである。タイム アンが先住情民であるとすれば，原初的に扇頂部に居住していたのはこれらのタ イムァン村落であり(33)，それぞれの扇状地の灌溉を掌握していたことになる。 ナムヒー扇状地では，1950年代に拈ける水利組織においてさえ，水路Dを管理す る水利官がバーンターホームァンに䁂かれている（表 1，図 5)。

\section{2 タイムァン村落の行政組織と水利機構}

契際の水利組織の上では，タイムァンの用水管理への関わりも扇状地ごとのタ イムァン村落群のまとまりも，明確には現れてこない。扇状地部のタイムァンが 原初的に形成していたはずの水利組織の形態は，むしろ行政組織の中に残存して いる。

タイムァンは行政単位ロンを3つ持っていた（図3）が，それぞれは地理的に まと孔りを見せている。ロンサーイはナムオッ扇状地に，ロンホンはナムヒ一扇 状地に，ロソホイは束南部の村落群に刘応するのである（因 4)。

タイムテンよりずっと村落数の多いレークノイが1つのロンしか持たないのに 刘し,タイムァンは地域ごとにロンを形成している。この地域ごとのまとまり はタイムァンの生活上の﨔位として何らかの意味を持っていたと考えるのが自 然であろら。それは，周辺支谷といら地域的まとまりであり，ナムオッ扇状地， ナムヒー扇状地という滥溉の系のまとまりであった。 


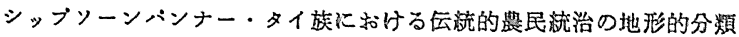

6 大水路のうち，ロンサーイ内のタイム ンン村落が用いるのは水路 $\mathrm{A} \cdot \mathrm{B}$ ，す なわちナムオッ扇状地を㵎す水路である。一方，ロンホン内のタイムテン村落が 用いるのは水路 D・E，すなわらナムヒ一扇状地を潤す水路である（図 4)。ロン 所属村落群と同一扇状地上の水路の受益村落群との間には，明らかな相関関係が 認的られる(34)。

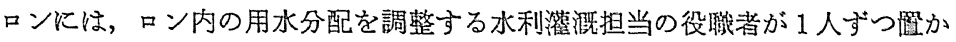
れていた [歴四：3]。これは扇状地が灌溉の系としてまとまりを持つことの反映

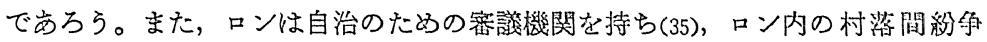
はこの審議機関を通じて調停された［歷九：97-98]。紛争の中には水争いも含ま れていたはずである。水争いは同一の灌溉の系に属する村落間に起こるものであ るから，扇状地のみの灌溉の系が形成されていた段階が過去に存在したとすれ ば，その時点での水争いはロンの領域内で帰結したわけである(36)。

ナムオッ扇状地の場合は，扇状地灌溉システムの要である扇面部村落 (1)(37) にロンの長，扇端付近最下流部に立地する村落にロンの副長が蹎かれている（四 3)。これは，最上流，最下流の村落にそれぞれ正，副水路長を聞いた（Iー2（4））という原初的扇状地灌溉の水利組織の特徽が，自治組職上に反收され残存 している事例とは需えないだろらか。

以上から，盈地内タイムァンは，灌溉の系としての扇状地のまとまりを些確に 自治組織を形成していたと結論できよう。このようなタイムフン自治組䋘の存任 は，かつて扇状地ごとにタイムァン自身が管理する灌溉体系が発邀していたとい らことの有力な傍証となる。

\section{$\mathrm{N}$ クンファンツァオと水利淮淮}

\section{1 クンファンツァオの村落立地}

クンファンツァオ村落は，扇状地部，沖䅡平野部を間わず，经地全体に分仰し ている（四6）。これをタイムァンの村落分报（因 4）との此校といら䚋点で見れ ば，村落が沖䅡平野部にまで広がっていることがクンファンツァオの忖染分行の 特徽と言えよう。

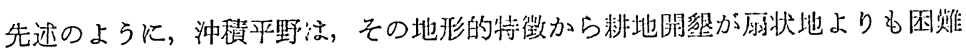
である。閏墾に先だっては排水を軸とする広域水利施設越設が必須であった。そ して，その建設には比䔩的大量の労倒力の動員，管理が不可火である。クンファ ンツァオ村落の沖䅡平野への入枮は，それ自体，広域水利施設㾏没に阅わる上位 
東南フジフー櫪央と文化一 No. 20, 1991

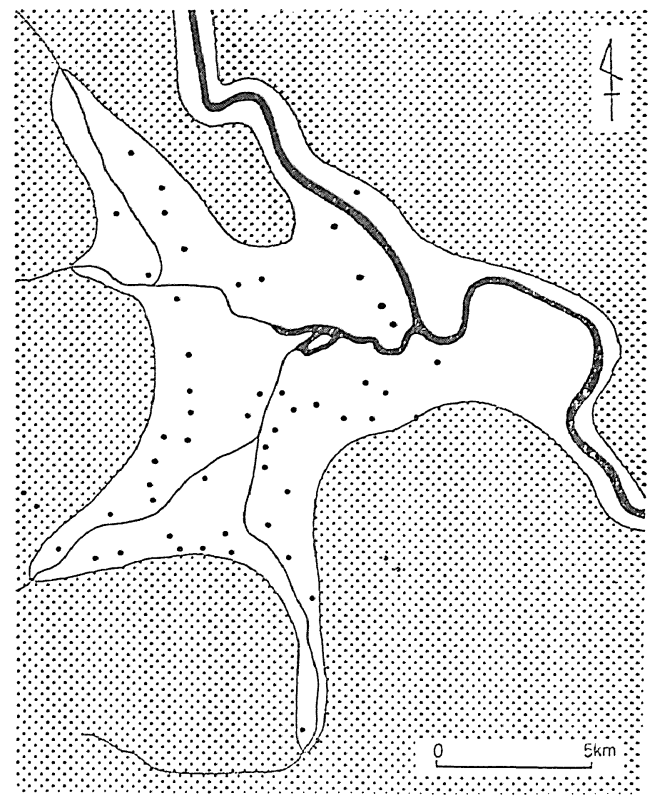

図6 クンファンツァオ村 落の分布

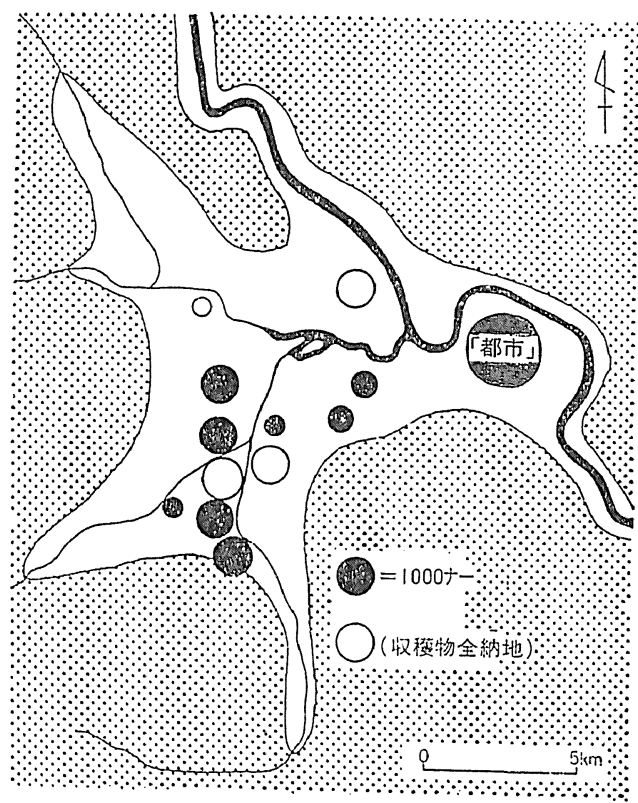

図 7 王田の分布 
権力の存在を想起させる。

ツニンフン盆地における沖積平野灌溉の主要な万法は，大水路の存在形態（罒 2) からも明らかなように，扇状地を流下する水路を引き能ぐといら方法を取っ ていた。その水路の扇端直下から排水口まで，すなわら沖程平野を流れる部分 は，沖積平野住民としてのクンファンツァホが上位権力の統率のもとに延舆した と考觉るのが自然である(38)。

2 クンファンツァオと沖積平野部の水利機鹤

クンファンツァオと水利灌溉との密接な関わりは，水利組織上に表れている。 すなわち，資料中に表れる水利官は，一例を除き，すべてがクンファンツナオ村 落に置かれている（表 1 ，図5）。

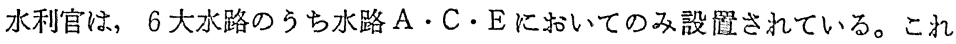

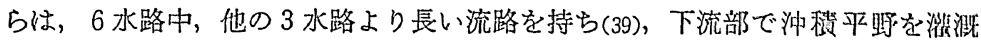
している(四2)。

また，水利官が置かれる村落は水路下流部，特に沖積平野部に多く分布してい る。その他は，ナムオッ，ナムヒー拉よび水路Cとして使われる河川が盆地に流 入する地点にそれぞれ一村ずつ存在する。水路 $\mathrm{A} ・ \mathrm{E}$ に拈いては，下流侧の水利 官に上流側の水利官より高位の称号パヤーが与えられている（図 5)。

以上から，統治権力による水利楼桠の整備扣よび水利官設洋は，水路下流蔀与 なわち沖積平野部の灌溉を主目的として行われたと想定される。沖程平野部に特 ける多数の水利官の存在は，それを直接に物語っている。水利官が三河川上流に 置かれたのは，その地点がそれより下流にわたる水がかり全域の用水を党握でき

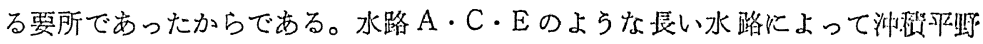
を灌溉するには，上流，下流の水利官が組織的に连㑺して用水管理を行ら必㫫が あったのである。

このような沖䅡平野灌溉のための水利機桃において，夷際に用水管理环邪を行

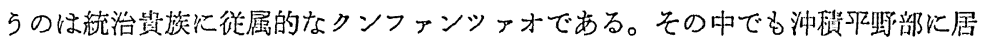
住するクンファンツァオにとっては，自らが沖積平野耕作の当琼者で方るため，

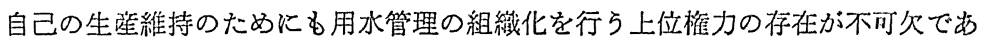
った。 
東葻アジァー歷央と文化一 No. 20, 1991

\section{おわりに一屡望にかえて}

以上の考察により明らかにされた内容は，以下のように要約される。第一に，

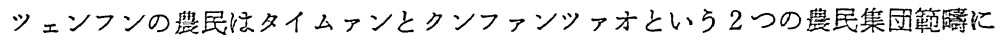
大別され，先住者とされるタイムァンは自銜的な存在であるのに対し，統治権力 成立後に入植したクンファンツフオは統治権力への従属度が高かったということ である。第二には，タイムァンは支谷や扇状地など殹灌浱が容易な地域に居住 し，原初的には自律的に用水管理を行っていたということである。第三には，沖 䅡平野といら灌溉・排水が困難な地域にはクンファンツァオが居住し，彼らが統 治椎力による組繊化のもとに開懇と生産を行ったということである。

支谷や扇状地，すなわち統治権力の灌涯に対する積極的介入の必要性が認めが たい地域は，基本的には自律的璴民タイムァンの世界であり，統治権力は限定的 にしかこの世界に介入しなかった。一方, 沖積平野, 寸なわら水稲耕作を行ら上 で広域水利施設と用水管理機構の存在が不可欠な地域は, 統治権力の従属民クン ファンッ>オの居住地域であり, 統治権力はその灌溉と水路維持に積極的に関わ っていた。つまりツェンフンは，統治権力によって均質的に統治された領域では なく，直挼的統治がなされる領域と器民自治が残存する領域とに分かれていた。

このように統治権力の情耕管理者的性格が限定的にしか表れない地域では, 統

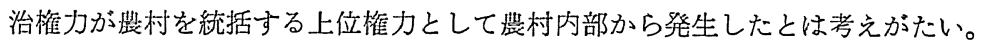
つまり，ツェンフンに拈ける䝮民統治は, 統治権力それ自体が発生, 存続する必 然性を付与するものではなかったのである。

それでは統治榷力の存在理由としては何を想定したらよいのだろらか。篗者 は，ツェンフンの統治榷力が「都市」を拠点としていたことに注目したい。「都 汸」は盆地東端の润泠江近くにあり（図 7)，外部より到来する者はこの付近か ら盆地に入ってくる。つまり「都市」は，交易・軍柰の拠点の1つ位置してい たことになる。この「都玄」の機能の分析は, ツェンフン統治権力の坐格を明ら かにしていくために不可欠な作業であるう。

一方，ツェンフンの灌溉管理は，加治らの指摘する「統治権力の経港基盤確 立」といら観点から更に検討される必要がある。ッェンフンの王田の分布（四7） 它見ると，王田は主に沖程平野部に存在している。沖積平野部には官僚田も多く ある。つまり，統治権力の沖穔平野鹳溉への介入は王田や官僚田の維持を主目的 になされた可能性がある(40)(41)。したがって，個々の王田がどの水路によって灌 
シップソーンパンナー・タイ族に括ける质流的费民䟽治の地形的分煩

溉され，どのように耕作されたかなどを検討していくことによって，ツェンフン の農民統治のあり方は一層明確かつ整合的にあらわれてくるだろう。

また，王田，官僚田の耕作に中心的に携わるクンファンツァオは，流治権力の 手によって入植させられている。つまり，クンファンツァオといら存在自体，統 治権力またはその抛点である「都市」を扶蓗するために設定されれたすのなのであ る。したがって，クンファンツァオ設膡による沖積平野を中心とした盆地開拓

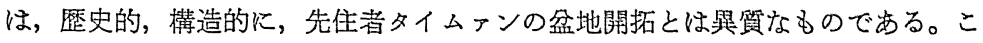
こに, ムアン政治構造の一体的, 停滞論的な理解, いわゆるムアンコスモロジー 論(42)を批判する要点が存在するように思われる。

最後に，本稿で取り上げたツェンフンの事例と先行吥觉に括ける他の盆地の孙 例を比較しながら，タイ族盆地国家の「䧱水力社会」的侧面をどう捉えるべきか について諭じてみたい。

田辺はチェンマイ盈地における灌溉体系として3つの類型を設定している [19 76 :690-693]。第 1 は支谷・扇状地型体系で，ツェンフンで見られるのと同じ方 式のものであり，農民レベルで用水供給源創出が可能である。第 2 の沖䅡平野型

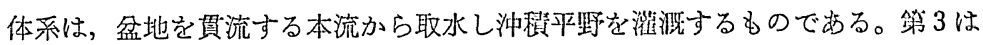

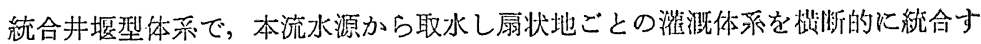
るものである。

また，田辺は，ラーンナータイでは国家権力が用水供給源を侴出・碓保するこ

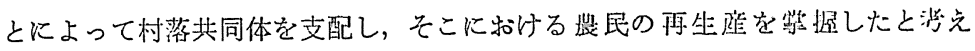
る。しかし，国家による用水規制が村落共同体の伝統的規制・惯行に依拠してい たため，国家傕力の支配は村落共同体内部にまで欺微されなかったという［由 辺, 1978]。

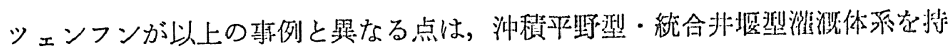
たないこと，つまり統治権力による用水供給源の創壮・碓保がないとで訪る。 ッェンフン盆地では，沖琵平野の灌溉は，小河川を水路に仕立てたり䍾状地水路

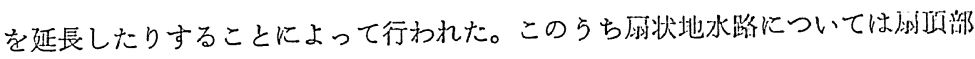

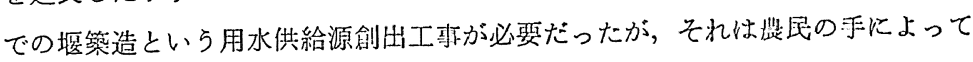

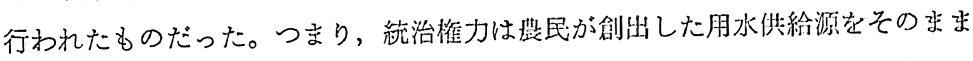
用いたのであり，流沙江や潣滄江に新たに用水供給源を㓱出したわけでけない。

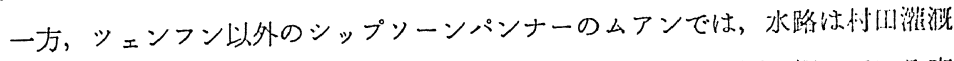
のためのタイムァン主導のものであり,タイムァンが用水供給源を握っている孙 
東南フジフー䜿史と立化一 No. 20, 1991

例が多数報告されている [馬場，1990：96-100］。これらのムアンには，クンフ フンツァオ村落も王田・官僚田も少なかった。ここには压倒的なタイムァン蕞民 の世界が存在しており，用水管理もタイムァンが自らのために行っていた事例し か認められないのである。ここでは，用水供給源どころか延長水路を掘削する試 みさえなされなかった。これは統治権力による用水管理なしにムアンが成立して いる事例である。

以上に表れてきたムアンごとの差異は，果たして何に起因するのだろらか。盆 地の規模(43)やその他の自然的状況の相違, 統治権力の大きさや性格の相違, あ るいはそれらの褶合作用など，様々な可能性が想定される。をた，それぞれの歴 央的環境も考虑されねばならない。いずれにせよ，稘盆地国家全般に関して 包括的に墖じるためには，今後，等例研究を更に積み重ねる必要がある。

現時点で言えるのは，統治権力による用水管理は，ムアンと呼ばれるタイ族的 政治統合成立のために必要不可欠なものではないといらことである。統治権力の 用水管理への介入は，沖䅡平野などの未墾地に統治者の直営地を開くことを主目 的としていた可能性がある。用水管理による愄民統治は，それに付随して副次的 に表れてくるものではないだろらか。

注

（1）森方桂の分類に従えば，この地域には主に南西タイ諸語を話すタイ族が居住してい る [三谷, 1984:66]。

（2）㑲四タイ諸語中の各語によって音, 声調の差があるが，ここではそれらを総括する

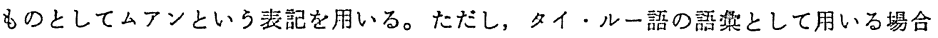
は，その音により近くムっンと表記する。ムフンは，城壁を持った都市的偗落そのもの を指すと同時に，その「都市」を中心として形成された国家的拆組みをむ示す㯒念であ る[石州，1975：18-19]。たたしこれとは別に、「都市」を示すチェンという語もある。

（3）タイ・ルー語の語句は，本文初出の際（注にのみ表机る場合は注において），発音

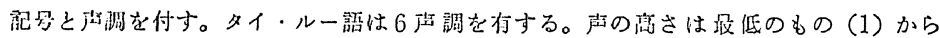

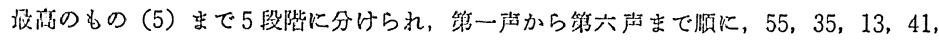
33，11となる。これら發音と声調の表記法は，巫，㜊に做った[巫；張，1981］。 （4）ラーンナータイ王国はタイ・ニフン旅の，シップッーンパンナー王国はタイ・ルー 嗾のムナン速合である。ラーンナータイ王国は13 世紀に成立したと言われる。

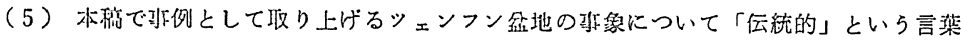
を伐用する场合は，「民主改莐」が行われる直前の 1950 年代前後の状沉を指すことが多 い。

（6）本塃は，1988年1月に名古屋大学文学部に提出した卒䒯諭文の一部をまとめたもの 
である。また，1989年1月には，卒業諭文とほぼ同じ内容の坏告を東南フシフ史学会閣

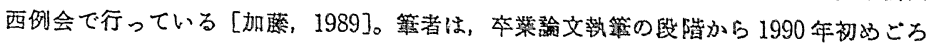

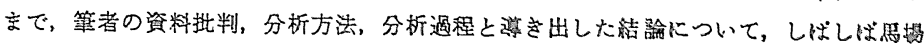

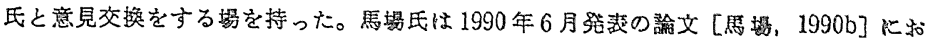

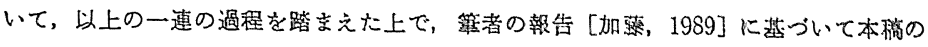
内容と重なる論点を提示しているが，篗者の詳細な分析過程には零及していない。とこ で省略された管者の分析過程が本稿中で初めて示される堨合は，その都度，注で指摘す ることとする。

（7）ツェンフンとはこの盆地の「都市」の名たが, 本稿に括いてはこの盆地に成立した 政治統合の名称として使用する。

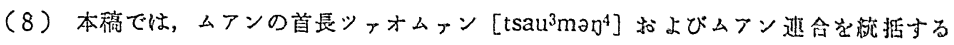
立場にある首長ッっオペンディンを，仮に「王」という菅葉で示す。

（9）『傣族社会整史調查』『西双版納傣族社会総合調査』として刊行されている。水稿で

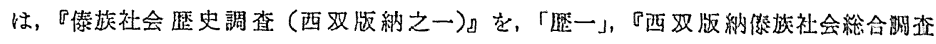
(一)』を「総一」のよらに略して示す。この資料は，当時の社会が「封建領主制」の段

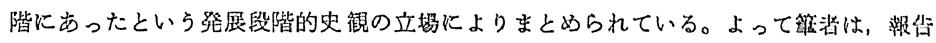
者の意味付けを可能な限り噔した生に近い形のデータ1つ1つを抽出し，それらを目的

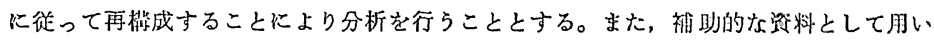
る『础湖王族世系』は「世系」と略して示す。

（10）雲南省内のメコン川は瀾洽江と呼ばれる。ナムホーンはッェンフンに为けるタイ・ ルー語の呼称である。

（11）ツェンフン湓地の地形と土地利用については，50万分の1地形図捛よびランドサッ トが，入手できるらち取も精度の高い資料である。そのため微地形の分析は不可能です った。また，扇状地部と沖程平野部の境界線を地因中に入れることもでさなかった。て の意味で以下の議諭は多少精密さを欠くことになるが，現段階での限界として誧了承い ただきい。

（12）調㚗時，すなわち 1950年代前後の水利櫂境である。

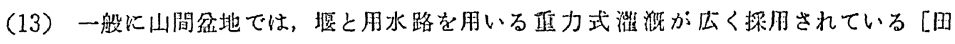
辺, 1976:690, 1978:183]。

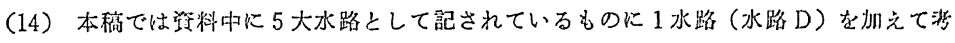
察する。それは 4 つの受益村落を持つ水路であり，5大水路中政小で 5 受益村浮しか掉 たない水路 Fに莎ずる規摸のものと考えてよい。

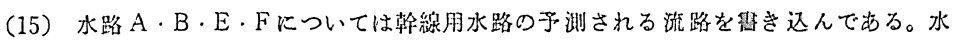
路 Cは，江南から流入する河川自体を用水路として用いている。水路Dの僦路㤕不明で ある。

（16）その中でも水路Bのみは筑造が比較的掘かった可能性がある。なぜなら，その水路 はおるにクンファンッナオ提民（IIで詳述する）か利用していたからである。

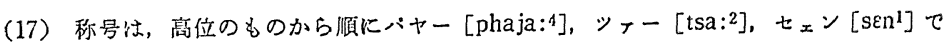
なる。 
束南アジァー匪史と文化一 No. 20, 1991

（18）支水路の水利官として簒能している場合もある。

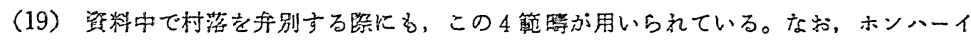
は王族の家内帮仕人として「都市」内の王族の集落に住む場合もあった。

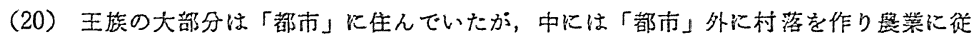
邪するものもあった。王族については稿を改めて論したい。

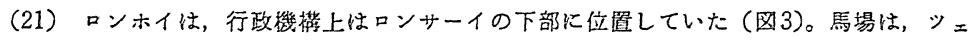

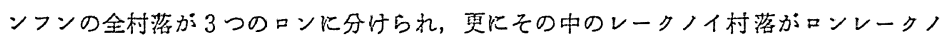
イに城成されたと記している［馬場，1990：89］が，それは資料の誤㜔であるう。正確

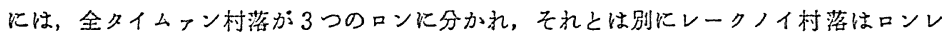
一クノイに編成されるのである。たたし，現地で得た情報（1989年3月18日，篗者の中 国語を用いた聞き取りによる。インフォーマントは, 新聞社勤務の当時 60 代半は（推 定）の男性である。彼はもと王族で，象管理の官僚呀めたこともある。彼によれば， ロンレークノイはロンサーイの一部と見なされることもあったといら。また，馬場の用 いた资料中にはロントンという名のロンが現れるが，それは図3のロンホイに該当する と思われる。

（22）例外的なるのもあるが，それは特殊状況にあった村落である。例えば，タイムっン のロン中のホンハーイ村落は, ロン内の特定のタイム ンン村落の徒属村落的立場にあっ た。

（23）タイムァンがムアンの先住民であること，クンファンッァオが多くムフン外に出自 を持ち，紿治者屏により近い存在であることは，馬場の諭文中にも記されている[馬

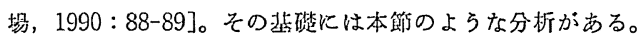

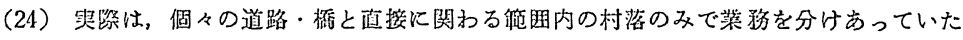
[歷四：141-145]。その中にクンファンッァオ村落が含まれる政例もあったか，その場

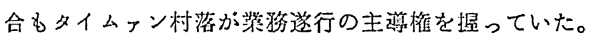

（25）水利施設を修筑すへきき時期に合わせて工挑を行らよ5命令を出すといった関わり方 が主なものであったと考克られる[張，1981］。

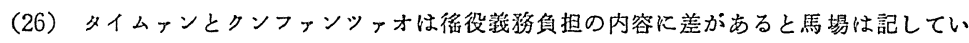

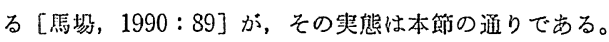

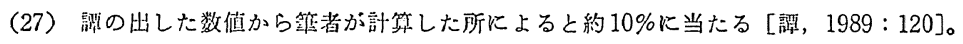

（28）ッェンフンの全村洛について所属牛地の程頻・面頛が示されているわけではないの

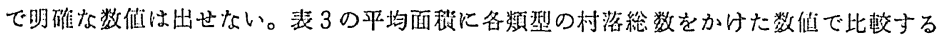
と次のよらになる。官你田はタイムェン村落 9600 ナーに対しクンファンッナオ村洛

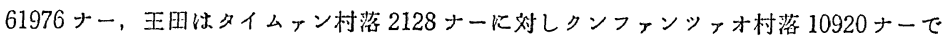

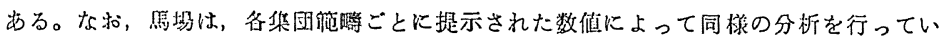
る [樶永, $1990: 93]$ 。

（29）排地面槛の俑りから予测されるよらに，タイムァン村落からクンファンッァオ村落 への耕地贷出の例が多い。タイムァンの上納米負担は, 倛出耕地からの「小作料」によ って臾饮上经減される。なた，岱出耕地の所有村であることを理由に，缺役をクンフ ンッァオ村落に呞代りさせるタイムっン村落もあった。 


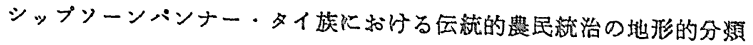

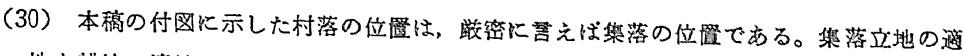

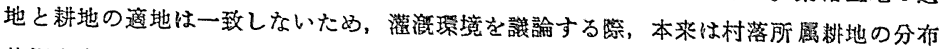
状況も考䈍されるべきである。しかし，村落所属耕地の分布状況は不明である。また， 村落は集落のまわりに個々の領域を持ち所属耕地は領城内にの及存在するため，栔落と

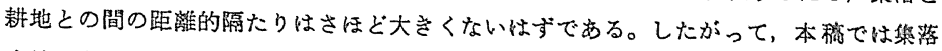
立地をもとに竓論を進める。

（31）水路掘削は, タイムケンに担われるべき「熖役」,カーンムテンの1つとされてい る。また，水路 $\mathrm{A}$ の水利官（20 舀の村落のもの）の次の上5な管葉が资料中にある。

「タイムテンがいて（現れて）はじめて水路ができ耘地が開かれた。耕地が閵かれては じめてッァオ(統治者)が現れた。ッフォが現れてはじぬてレークノイ、ホンハーイが 現れた。レークノイ、ホンハーイの田は後から開かれたものである。」これらの情隺は, 1955 年 4 月に出された報告望による [歷四: 139-140]。

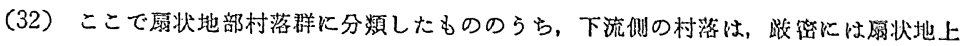
にあるとは言えない。沖䅡平野の端にあると見たほうがよいるのさ市る。いずれにし ても微地形㧍よび土地利用状沅が不明であるため，これ以上の铰諭はでさない。本稿

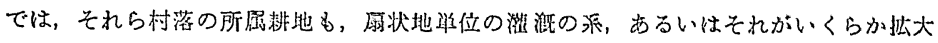
されたものの中で，比較的容易に漼溉できたと捉えて諭を進める。

（33）一般に扇頂と扇端は最初の集落立地として避济れやすい。これらの原项の村洛は,

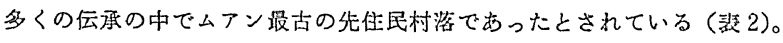

（34）水路 Bは主にレークノイが利用する水路であり，タイムテンでは村洛棌号 1 の村㴽

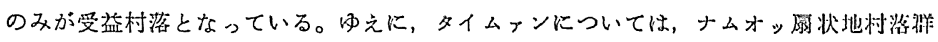

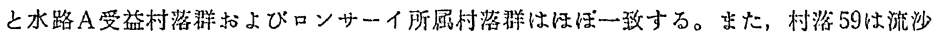

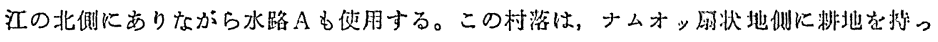
ていたと侾えられる。

（35）ロン所属の主要村落の代表渚を蝾成員とする。

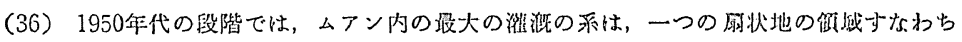

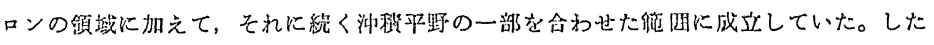

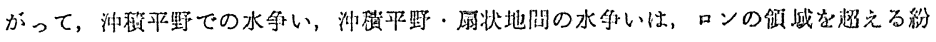

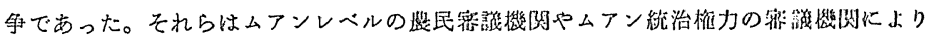
調停されたと考えられる。

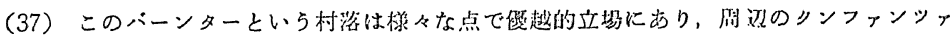

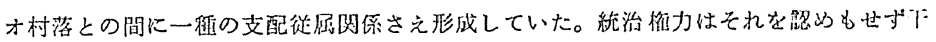
涉もしないといら㴧度を取っていた。

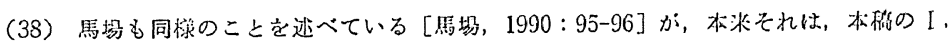
四および N-1の設諭を踏まえた上で示されるへきものである。

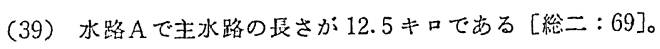

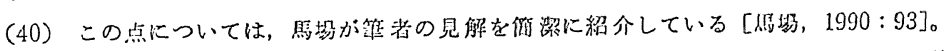
そのよらに結論するに到った過程は，前半部分のみ本候のりに扰いて示されている。後 半は符を欧めて提示したい。 
東南アジアー歷史と文化一 No. 20, 1991

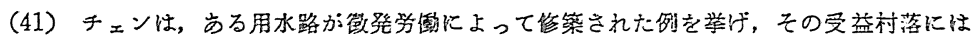
かなりの监のナーツォオ（王田，官尞田）があることを指摘している[Chen, 1949 ：

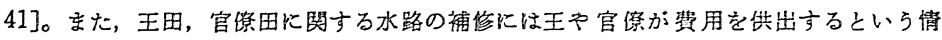

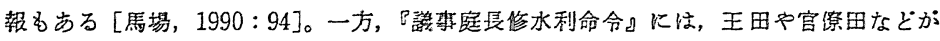
干ばつのために荒廃することは許されない旨，明記されている[張，1981：60］馬場， $1990: 103]$ 。

（42）東南フジフ央学会第 38 回研究大会，共通論題「東南アジア史の中の雲南」(1987年 12月6日）における田辺繁治のコメント，および石井・桜井の「ムアン」国家の考え方 [石井・桜井, 1985] Кあらわれている。

（43）ここに举げた例では，チェンマイ, ツェンフン, シップッーンパンナーの他のムフ ンの順に規模がささくな。

参考文献

〈一次䵍料として使用したもの〉

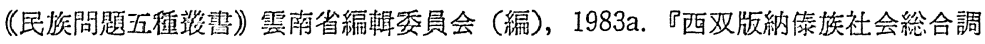
查 (一)』昆明 : 雲南民族出版社

一，1983b-f. 『傣族社会歷史調查（西双版納之一～五)』昆明：雲南民族出版 仕

一，1984a.『西双版納傣族社会総合調查（二）』昆明：雲南民族出版社

一，1984b. 『傣族社会歴史調查（西双版納之六）』昆明：雲南民族出版社

雲南調查組 (編)，1958. 「西双版納詈洪傣族民主改革以前的領主経済」『民族研 究工作的躍進』：253-303 面所収, 北京: 科学出版社

雲南省編集組 (編)，1985a，b.『傣嗾社会歷失調㚗 (西双版納之七～八)』昆明：

雲南民族出版社

一，1987. 『傣族社会歷史調永（西双版納之十）』昆明：雲南民族出版社

一，1988.『漛㵀社会歴史調查（西双版納之九）』昆明：雲南民族出版社

军南省少数民族古籍整理出版婗㴻升公室 (螎)，1987. 猛测王族世系』昆明：雲

陶民族比恢社

〈その他の参淡文苚〉

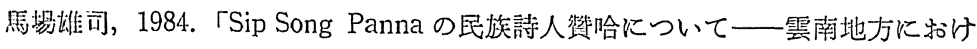
る文化衫合の一形熊として」『東南アジア一歴史と文化』13（斗南アジア史 学会維)：29-58頁所収, 東京: 平凡社。

一, 1990a.「雲南タイ・ルー族のツァーンハプ (㸛哈)一一歌(ハプ) を專門と

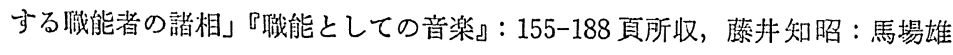




\section{シップソーンパンナー・タイ族における云梳的䍔民流治の地形的分影}

司 (編), 東京 : 東京書籍。

—1990b.「シップソーンパンナー王国の水利組織について一一ヶォロンパー サーッの機能に関して」『東南アジア研究』28-1（京都大学東南アジア研究セ ンター編)：83-107 頁所収, 京都 : 京都大学東南アジア砟㠰センター。

Chen, Han-seng, 1949. Frontier Land Systems in Southernmost China, New York : Institute of Pacific Relations.

張公瑾, 1981.「西双版納傣族歷史上的水利灌溉」『思想踽線』1981-2（零南大学 学報編輯部編) 60-63,66頁所収, 昆明: 雲南人民出版社。

巫凌雲 ; 張秋生, 1981. 『西双版納傣語文概況』昆明：雲南民族出版社。 石井米雄, 1975.「歴史と稲作」『タイ国—ひとつの稲作社会』：16-45真所収，

東京 : 創文社。

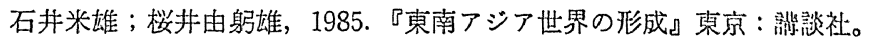

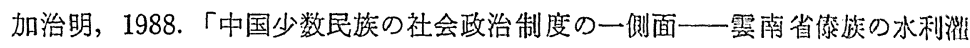

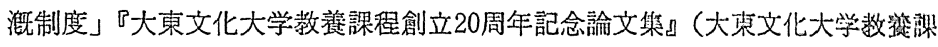

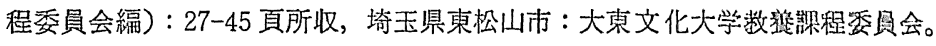
加藤久美子，1989.「1950年代におけるタイ・ルー族の『身分制』とムァン『支 配』—ムァンツェンフンの事例を中心に」東南アジア史学会関酉例会（1月） 報告ドラフト。

三谷恭之，1984。「東南アジア諸言語の系譜」『東南アジアの民族と症史』：58-78 頁所収, 大林太良 (編), 真京 : 山川出版社。

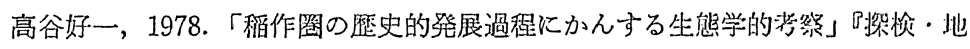

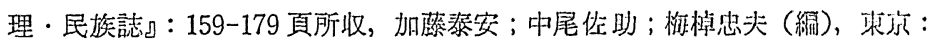

中块公諭社。

田辺繁治, 1973. 「雲南シップソーンパソナーの統治形㤵に圆する一将祭一ール ゥ族の政治組織・土地制度を中心に」季刊人類学』4-1（京都大学人䫏学倾究 会編)：131-167頁所收，東宗：㩐談社。

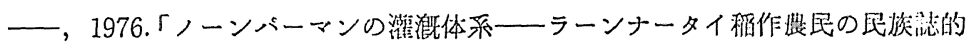
研究 (1)」『国立民族学博物館研究報告』1-4（国立民族学博物馆編）：671-777 頁所収, 京都：贆団法人导族学振興会。

一，1978.「Lānnāthai ゆ水利形態に関する考察—-mŭang-faiをめぐる 2,3

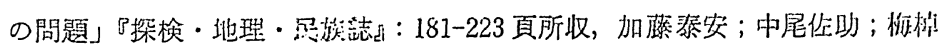
忠夫 (編), 東就：中夹公椧社。 
東南フジフー歷央と文化一 No. 20, 1991

一，1984.「神々の弁証法—タイ・ルー族の守護霊讋礼、雲厥の照葉樹のる とで』：131-172頁所收，佐々木高明 (編), 京京：日本放送出版協会。

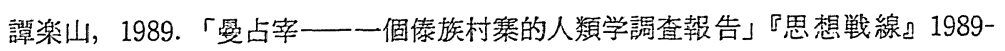

增刊 (雲南大学学報編輯部編)：117-125 頁所収, 昆明：雲南人民出版社。

\section{Rule in Chiang Hung, \\ a "Basin Polity" of Sipsongpanna-Tai; From Physiographic Point of View}

\section{Kumiko KATO}

There were a large number of "muang polities" of the Tai in the northern part of continental Southeast Asia. A muang polity would typically be established in an inter-mountain basin and was independently governed by its own king and his family. The polities sometimes formed leagues of muangs, such as the Lannathai league and the Sipsongpanna league etc. Ishii called these societies "quasi-hydraulic societies", as the irrigation systems were controlled by the "state power". This article presents an illustration from a physiographic point of view of how a muang polity governed its people in a "quasi-hydraulic society" by analyzing the case of Chiang Hung, a muang whose king was also the overall king of the Sipsongpanna league. Most of the information used in this analysis is obtained from the reports of a survey carried out in the 1950's for the purpose of land reform by the Peoples' Republic of China.

The Chiang Hung basin can be divided into two areas, the alluvial fans area and the alluvial plain area. Irrigation was comparatively easy in the former but more difficult in the latter. It is said that at first each alluvial fan had its own irrigation system controlled by those who located on the apex part, where they could control the intake of the main canals from the river.

Chiang Hung had two types of inhabitants: the Tai Muang, and the 
シップソーンパンナー・タイ族における云統的農民流治の地形的分類

Kun Huan Chao. According to traditions, the Tai Muang's ancestors had been the initial Tai inhabitants of the basin. On the other hand, many villages of the Kun Huan Chao had close relations to the royalty of this muang when they were established. Some Kun Huan Chao villages were established by servants of the king or high-ranking officials, while others were established by Kun Huan Chao immigrants invited by the royal house. Both the conditions of the arabl land and the kinds of labor found seem to suggest that the Tai Muang were more independent of the monarchs than the Kun Huan Chao were.

Almost all the Tai Muang in the basin lived in the alluvial fans area, where irrigation was relatively simple. Of the bigger canals, the Tai Muang in the basin used only the canals on the two biggest alluvial fans. The oldest and dominant Tai Muang villages are found in both of the apex parts of the alluvial fans, which are the most important for operating the irrigation system on alluvial fans. Also, each of the two alluvial fans had a self-governing body of the Tai Muang, the so-called long, with an irrigation leader whose power extends over the area of the long, or alluvial fan. The above facts suggest that the Tai Muang may originally have made and operated an irrigation system on each of the two biggest alluvial fans without any support of the power of the "state", and that their selfgoverning bodies derived from the former alluvial fan irrigation control group.

Kun Huan Chao villages were located not only in the alluvial fans area but also in the alluvial plain area, which must have originally consisted of swamps. These areas had to be drained to be brought under cultivation. To drain and cultivate this area, the existence of the monarchy, or the "state power" was essential. It could settle the Kun Huan Chao there and organize its labor for the task of extending the main canals, which had already been constructed by the Tai Muang from the apexes to the lowest parts of the alluvial fans. Following this, to ensure the cultivation of this area, the state power gave titles to the irrigation leaders, especially to those of Kun Huan Chao villages located in the alluvial plain. 
東南フジフー歷史と文化一 No. 20,1991

In conclusion, it can be said that the alluvial fans area was basically the Tai Muang's autonomous area, over which the "state power" did not effectively wield power. They originally made and operated the irrigation systems by themselves. The alluvial plain area was brought under cultivation by "state power" and was ruled more strongly than the alluvial fans area. Thus the power of the royalty or the "state power" did not originate in farm villages, as the king's power was neither effective nor essential to the Tai Muang.

This case study of Chiang Hung shows that some of the "muang polities" were "quasi-hydraulic societies" only in a very limited sense. The author suggests that the hypothesis of "quasi-hydraulic societies" does not offer a sufficient explanation for the origins of "state power" in "muang polities". （所属：名占屋大学大学院, 